\title{
Impervious Cover and Stream Quality Prediction Based on Impervious Cover Model and Water Quality Index at Ciliwung River, West Java
}

\author{
Dwita Sutjiningsih
}

\begin{abstract}
The increasing impervious cover brings out a flashier hydrograph, elevated concentrations of pollutants transported from impervious surfaces to streams, altered channel morphology, and reduced biotic integrity. The subwatershed-scale $\left(5-50 \mathrm{~km}^{2}\right)$ is preferred for assessment studies, stream classification, and management planning.

The impervious cover model (ICM) correlates the percentage of subwatershed imperviousness and stream quality as well as outlines specific quantitative or narrative predictions for stream indicators within each stream category to define the severity of current stream impacts and the prospects for their future restoration. The National Sanitation Foundation Water Quality Index (NSFWQI) is one of analytical tools that commonly used to summarize water quality data, which converts the concentration data for nine water quality parameters into one of five Water Quality Rating (WQR).

The study aimed to test the applicability and conformity of both ICM and NSFWQI approaches for predicting stream quality of Ciliwung river, West Java, Indonesia. The ICM is applied onto 14 subwatersheds range from 6.9 up to $48.2 \mathrm{~km}^{2}$. The results of ICM prediction are two sensitive streams, four impacted streams, four nonsupporting streams, and four urban drainage streams. The WQR were determined based on water quality data from five stations: Atta'awun, Katulampa Weir, Kedung Halang, Pondok Rajeg, and Panus Bridge. Water quality at the most upstream station Atta'awun was rated "good" (73), while the other sites just at "medium" rating (61-64).
\end{abstract}

Keywords-Impervious Cover Model, Stream Categories, Stream Quality Prediction, Water Quality Index, Water Quality Rating.

\section{INTRODUCTION}

Up to the year 2003 more than two hundred scientific articles have documented the adverse impact of urbanization on one or more of four key indicators: changes in hydrologic, physical, water quality or biological indicators. In general, most research has focused on smaller watersheds, with catchment areas ranging from a few hundred acres up to ten square miles (ca. 0.5 $-25 \mathrm{~km}^{2}$ ) [1], [2].

The Impervious Cover Model (ICM) correlates the

Manuscript received April 12, 2016. This work was supported in part by the Universitas Indonesia.

Dwita Sutjiningsih is lecturer at the Department of Civil Engineering, Faculty of Engineering Universitas Indonesia, Kampus UI Depok, Depok 16424, West Java, Indonesia. percentage of subwatershed impervious cover (IC) and stream quality into four categories, ranging from "poor" to "excellent". The ICM also outlines specific quantitative or narrative predictions for stream indicators within each stream category to define the severity of current stream impacts and the prospects for their future restoration. The majority of research published since 2003 has confirmed or reinforced the basic premise of the ICM, although it has also revealed important caveats and limitations to its application. A reformulated conceptual ICM is strengthened to reflect the most recent science and simplify it for watershed managers and policy makers [3].

Water Quality Index (WQI) by the National Sanitation Foundation (NSF) was one of the analytical tools that commonly used to summarize water quality data. The WQI converts the concentration data for nine parameters water quality into one of five Water Quality Rating (WQR) [4]-[6].

The study aimed to test the applicability and conformity of both ICM and NSFWQI approaches for predicting stream quality of Ciliwung river, West Java, Indonesia. Ciliwung watershed is divided into 14 subwatersheds range from 6.9 up to $48.2 \mathrm{~km}^{2}$. Estimation of IC were based on digital land use map 2009 provided by BIG (The Geomatics Information Agency), while the NSFWQI were calculated based on the water quality data uploaded by BPLHD Provinsi Jawa Barat (West Java Province Environmental Management Agency) at five stations: Atta'awun, Katulampa Weir, Kedung Halang, Pondok Rajeg, and Panus Bridge.

\section{Methodology}

\section{A. Framework of The Study}

Functional relationships between watershed imperviousness and stream quality as presented in Fig. 1 is adapted from suggested protocol for conducting a watershed monitoring study [7]. The protocol emphasizes comparative sampling of at least 20 urban subwatersheds of different increments of imperviousness, where the data on hydrologic, morphologic, water quality, habitat and biodiversity variables within each subwatershed are collected. Series of undeveloped and undisturbed reference streams are also monitored for comparison purposes. The sampling data are analyzed to determine the relationships between imperviousness and stream quality. 
For the purpose of this study, the protocol is focused just on the determining of subwatershed imperviousness and water quality variables (highlighted boxes in Fig. 1).

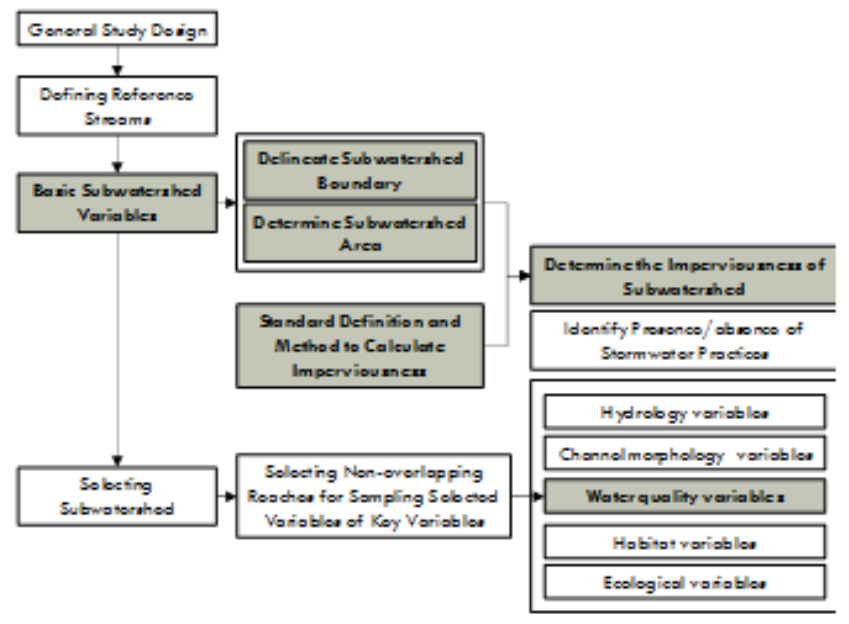

Fig. 1 Functional Relationships Between Watershed Imperviousness and Stream Quality. Adapted from [7]

\section{B. Watershed Imperviousness}

Imperviousness as a consequence of urbanization represents the imprint of land development on the landscape. It is composed of two primary components: the rooftops and the transport system [7]. However, in this study the imperviousness of subwatersheds is defined as Total Impervious Area (TIA) and determined based on digital land use map 2009 [8]. Imperviousness of the subwatershed is equal to the ratio between TIA and Total Subwatershed Area.

\section{Impervious Cover Model}

As describe in [3], the Impervious Cover Model (ICM) correlates the percentage of subwatershed imperviousness and stream quality, which is classified into four categories, ranging from "poor" to "excellent". The ICM also outlines specific quantitative or narrative predictions for stream indicators within each stream category to define the severity of current stream impacts and their restoration prospects in the future. In general, ICM will predict the following: (i) Streams with less than $10 \%$ IC continue to function as "sensitive streams", and are generally able to retain their hydrologic function and support good to excellent aquatic diversity; (ii) Streams with 10 to $25 \%$ IC behave as "impacted streams" and show clear signs of declining stream health. Most stream health indicators fall in the fair range, although some reaches with extensive riparian cover may score higher; (iii) Streams that possess between 25 and $60 \%$ IC are classified as "nonsupporting streams", as they no longer support their designated uses in terms of hydrology, channel stability, habitat, water quality, or biological diversity. Nonsupporting streams become so degraded that it may be difficult or impossible to fully recover predevelopment stream function and diversity; and (iv) Streams within subwatersheds exceeding $60 \%$ IC are often so extensively modified that they merely function as a conduit for flood waters. These streams are classified as "urban drainage" and consistently have poor water quality, highly unstable channels, and very poor habitat and biodiversity scores. In many cases, these urban streams are eliminated altogether by earthworks and/or storm drain enclosure.

Also stated in [3], the subwatershed-scale $\left(5-50 \mathrm{~km}^{2}\right)$ is preferred for assessment studies, stream classification, and management planning based on the following argumentations: (i) the influence of IC on hydrology, water quality, and biodiversity is readily apparent; (ii) subwatersheds are small enough that there is less chance for confounding pollutant sources to confuse management decisions; (iii) subwatersheds tend to be within a few administrative boundaries, where it is easier to establish a clear regulatory authority and incorporate the stakeholders into the management process; and (iv) in a time frame, the size of a subwatershed allows rapid monitoring, mapping, and other watershed assessment steps.

During the period of 1984-2003, more than two hundreds scientific articles have documented the adverse impact of urbanization on one or more of the four key indicators: changes in hydrologic, physical, water quality or biological indicators [1], [2]. Increasing IC will in turn bring out a flashier hydrograph, elevated concentrations of pollutants transported from impervious surfaces to streams, altered channel morphology, and reduced biotic integrity [9]. The majority of research published since 2003 has confirmed or reinforced the basic premise of the ICM, although some studies have also revealed important caveats and limitations to its application [3].

The original version of ICM was reformulated and reported in 2009 includes three important changes: (i) the IC-stream quality relationship is expressed as a "cone" that is widest at lower levels of IC and progressively narrows at higher IC, (ii) the cone width is greatest for IC values less than 10\%, which reflects the wide variability in stream indicator scores observed for this range of streams, in order to prevent the misperception that streams with low subwatershed IC will automatically possess good or excellent quality, and (iii) the transition between stream quality classifications is expressed as a band rather than a fixed line, which reflects the variability in the relationship between four key-indicators and the qualitative endpoints that determine stream quality classifications [3].

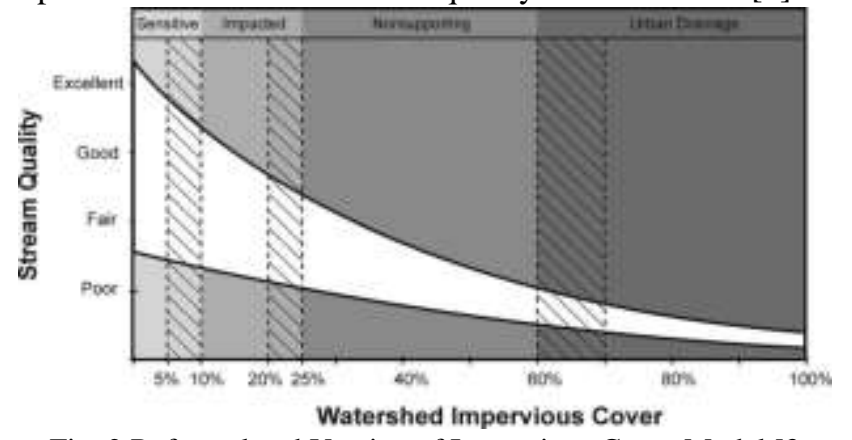

Fig. 2 Reformulated Version of Impervious Cover Model [3

\section{Water Quality Index and Water Quality Rating}

The National Sanitation Foundation (NSF) Water Quality Index (WQI) is one of the analytical tools that commonly used to summarize water quality data. The WQI converts the concentration data for nine parameters water quality into one of five Water Quality Rating (WQR) [4]-[6]. 
TABLE I: WATER QUALITY PARAMETERS ACCORDING TO NSFWQI.

\begin{tabular}{llc}
\hline \hline Water Quality Parameters & Unit & Weighted Factor \\
\hline Dissolved Oxygen (DO) & $\mathrm{mg} / \mathrm{l}$ or \%sat & 0.17 \\
\hline Fecal Coliform & count/100 ml & 0.16 \\
\hline $\mathrm{pH}$ & - & 0.11 \\
\hline Biochemical Oxygen Demand (BOD) & $\mathrm{mg} / \mathrm{l}$ & 0.11 \\
\hline Temperature Change & ${ }^{\circ} \mathrm{C}$ & 0.10 \\
\hline Total Phosphate $\left(\mathrm{PO}_{4}\right)$ & $\mathrm{mg} / \mathrm{l}$ & 0.10 \\
\hline Nitrate $\left(\mathrm{NO}_{3}\right)$ & $\mathrm{mg} / \mathrm{l}$ & 0.10 \\
\hline Turbidity & $\mathrm{NTU}$ & 0.08 \\
\hline Total Suspended Solid (TSS) & $\mathrm{mg} / \mathrm{l}$ & 0.07 \\
\hline Total & & 1.00 \\
\hline \hline
\end{tabular}

The NSFWQI is calculated based on (1). An online calculator is accessible [5]. Using this calculator, it is possible to calculate WQI with incomplete/missing data.

$$
W Q I=\sum_{i=1}^{n} Q_{i} W_{i}
$$

Where,

$Q_{i}=$ sub-index for i-th water quality parameter;

$W_{i}=$ weight associated with i-th water quality parameter;

$n=$ number of water quality parameters.

The NSFWQI are classified according to the following categories:

TABLE II: WATER QUALITY INDEX AND WATER QUALITY RATING.

\begin{tabular}{cc}
\hline \hline Water Quality Index (WQI) & Water Quality Rating (WQR) \\
\hline $90-100$ & Excellent \\
\hline $70-90$ & Good \\
\hline $50-70$ & Medium \\
\hline $25-50$ & Bad \\
\hline $0-25$ & Very Bad \\
\hline \hline
\end{tabular}

\section{E. Watershed Impervious Cover and Stream Quality}

According to [10] impervious cover (IC): (i) are a critical contributor to the hydrologic changes that degrade waterways, (ii) are a major component of the intensive land uses that do generate pollution, (iii) prevent natural pollutant processing in the soil by preventing percolation, and (iv) serve as an efficient conveyance system transporting pollutants in to the waterways.

The widely accepted theory is that IC changes stream hydrology, which degrades stream habitat, and in turn leads to reduced stream biodiversity [1].

In general, the sites nearest the headwaters have the highest water quality rating with significant decreases in water quality occurring downstream, particulary in urban-impacted areas [9].

\section{STUDY AREA}

The study area located at Ciliwung watershed, West Java, Indonesia. Ciliwung springs in Mount Gede-Pangrango, flows northward through Bogor, Depok, Jakarta and debouches into Jakarta Bay. The rate of urbanization in Jakarta, Depok and Bogor is very alarming, which the consequence of increasing impervious cover. Inline with the aim of the study, Ciliwung is divided into 14 subwatersheds ranging from 6.9 up to $48.2 \mathrm{~km}^{2}$ from Upper Ciliwung at the upstream until Lower Ciliwung at the downstream.

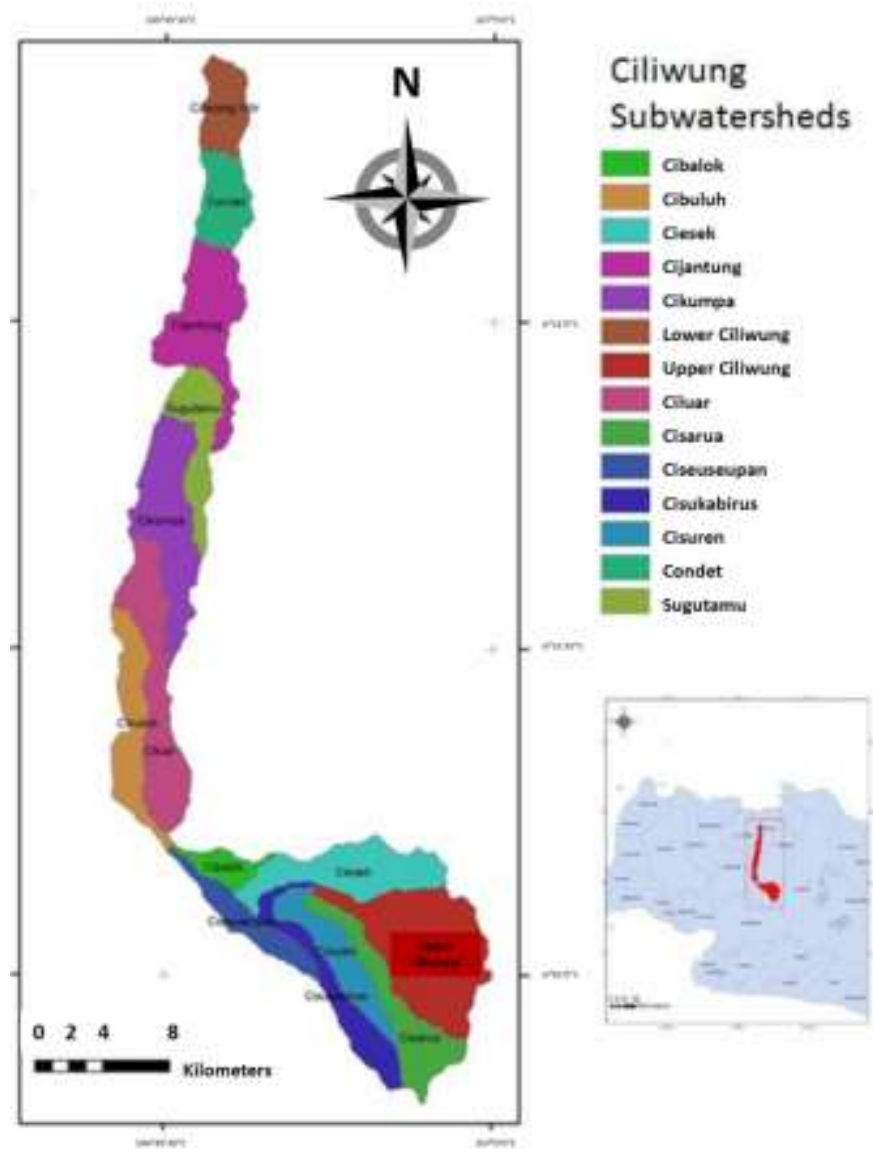

Fig. 3. Subwatersheds of Ciliwung River, West Java, Indonesia [8].

The subwatershed imperviousness is determined based on digital land use map 2009 [8], and the result is presented in Table III. The range of imperviousness is from $7.7 \%$ up to $85.6 \%$. Correlation between imperviousness and WQI are derived at five stations (Table IV).

TABLE III: SUBWATERSHEDS OF CILIWUNG.

\begin{tabular}{lccc}
\hline \hline \multicolumn{1}{c}{ Subwatershed } & $\begin{array}{c}\text { Total Area } \\
(\mathrm{Ha})\end{array}$ & $\begin{array}{c}\text { Impervious } \\
\text { Cover (Ha) }\end{array}$ & $\begin{array}{c}\text { Subwatershed } \\
\text { Imperviousness }\end{array}$ \\
\hline Upper Ciliwung & 4820.3 & 657.0 & $13.6 \%$ \\
\hline Cisarua & 2201.9 & 251.1 & $11.4 \%$ \\
\hline Cisuren & 1686.8 & 129.5 & $7.7 \%$ \\
\hline Cisukabirus & 1769.8 & 154.5 & $8.7 \%$ \\
\hline Ciesek & 2724.3 & 341.4 & $12.5 \%$ \\
\hline Ciseuseupan & 872.7 & 414.8 & $47.5 \%$ \\
\hline Cibalok & 691.9 & 145.6 & $21.1 \%$ \\
\hline Cibuluh & 2053.5 & 1194.4 & $58.2 \%$ \\
\hline Ciluar & 3287.3 & 1120.3 & $34.1 \%$ \\
\hline Cikumpa & 3231.5 & 1006.4 & $31.1 \%$ \\
\hline Sugutamu & 1726.6 & 1137.8 & $65.9 \%$ \\
\hline Cijantung & 3077.8 & 2020.7 & $65.7 \%$ \\
\hline Condet & 1471.7 & 1224.2 & $83.2 \%$ \\
\hline Lower Ciliwung & 1333.7 & 1141.6 & $85.6 \%$ \\
\hline \hline
\end{tabular}

TABLE IV: IMPERVIOUSNESS UP TO SAMPLING STATION OF CILIWUNG.

\begin{tabular}{lccc}
\hline \hline \multicolumn{1}{c}{ Station } & $\begin{array}{c}\text { Total Area } \\
\left(\mathrm{Km}^{2}\right)\end{array}$ & $\begin{array}{c}\text { Total Impervious } \\
\text { Cover }\left(\mathrm{Km}^{2}\right)\end{array}$ & $\begin{array}{c}\text { Imperviousness } \\
\text { up to Station }\end{array}$ \\
\hline Atta'awun & 48.2 & 6.6 & $13.63 \%$ \\
\hline Katulampa Weir & 151.8 & 20.9 & $13.79 \%$ \\
\hline Kedung Halang & 172.4 & 32.9 & $19.08 \%$ \\
\hline Pondok Rajeg & 205.2 & 44.1 & $21.48 \%$ \\
\hline Panus Bridge & 237.5 & 54.2 & $22.80 \%$ \\
\hline \hline
\end{tabular}


Following are water quality data at five stations.

TABLE V: WQI Parameters at Sta. Atta'awun 2013 [11].

\begin{tabular}{lrrrrrr}
\hline \hline & Apr & \multicolumn{1}{c}{ May } & Jul & Sep & Oct & Average \\
\hline DO & 7.5 & 7.17 & 6.18 & 3.97 & 6.03 & 6.17 \\
\cline { 2 - 7 } & 98.69 & 92.7 & 78.01 & 51.63 & 79.8 & 80.15 \\
\hline Fecal Coli. & 27 & 2,100 & 150 & 93 & 240 & 522 \\
\hline pH & 6.15 & 7.15 & 7.75 & 7.92 & 6.91 & 7.176 \\
\hline BOD & 3.5 & 2 & 3.8 & 2.2 & 2.5 & 2.8 \\
\hline Temperatur & 20.6 & 19.7 & 18.5 & 20.0 & 20.9 & 19.94 \\
\hline PO4 & 0.09 & 0.22 & 0 & 0 & 0.03 & 0.068 \\
\hline NO3 & 2.23 & 2.28 & 6.86 & 1.77 & 1.5 & 2.928 \\
\hline Turbidity & - & - & - & - & - & - \\
\hline TSS & 19 & 19 & 67 & 12.8 & 17 & 26.96 \\
\hline \hline
\end{tabular}

TABLE VI: WQI PARAMETERS AT STA. KATULAMPA WEIR 2013 [12].

\begin{tabular}{lrrrrrr}
\hline \hline & Apr & \multicolumn{1}{c}{ May } & \multicolumn{1}{c}{ Jul } & Sep & Oct & \multicolumn{2}{c}{ Averag } \\
\hline DO & 3.51 & 7.5 & 6.53 & 3.34 & 6.45 & 5.466 \\
\cline { 2 - 7 } & 45.09 & 93.58 & 78.39 & 42.83 & 82.86 & 68.91 \\
\hline Fecal Coli. & 28,000 & 35,000 & 1,500 & 350 & 150,000 & 42,970 \\
\hline pH & 5.933 & 7.99 & 8.02 & 8.07 & 7.9 & 7.583 \\
\hline BOD & 30 & 8 & 6.1 & 8.12 & 4.8 & 11.404 \\
\hline Temperatur & 26.1 & 24.4 & 22.3 & 26 & 26.1 & 24.98 \\
\hline PO4 & 0.12 & 0.62 & 0.45 & 0.44 & 0.04 & 0.334 \\
\hline NO3 & 2.27 & 2.85 & 11.39 & 2.48 & 2.22 & 4.242 \\
\hline Turbidity & - & - & - & - & - & - \\
\hline TSS & 32 & 38 & 71 & 20 & 22 & 36.6 \\
\hline \hline
\end{tabular}

TABLE VII: WQI PARAMETERS AT STA. KEDUNG HALANG 2013 [13].

\begin{tabular}{lrrrrrr}
\hline \hline & Apr & \multicolumn{1}{c}{ May } & \multicolumn{1}{c}{ Jul } & Sep & Oct & Average \\
\hline DO & 5.97 & 5.82 & 6.87 & 3.75 & 4.62 & 5.406 \\
\cline { 2 - 7 } & 76.25 & 73.49 & 83.52 & 47.59 & 58.72 & 68.09 \\
\hline Fecal Coli. & 2,800 & 2,700 & 4,300 & 1,500 & 15,000 & 5,260 \\
\hline pH & 6.34 & 8.09 & 7.11 & 7.8 & 7.41 & 7.35 \\
\hline BOD & 3 & 15 & 4.5 & 12 & 11.6 & 9.22 \\
\hline Temperatur & 26.9 & 26.2 & 24 & 26.5 & 26.6 & 26.04 \\
\hline PO4 & 0.11 & 0.69 & 0.19 & 0.3 & 0.06 & 0.27 \\
\hline NO3 & 2.03 & 2.92 & 11.42 & 3.31 & 2.05 & 4.346 \\
\hline Turbidity & - & - & - & - & - & - \\
\hline TSS & 12 & 50 & 89 & 24 & 26 & 40.2 \\
\hline \hline
\end{tabular}

TABLE VIII: WQI PARAMETERS AT STA. PONDOK RAJEG 2013 [14].

\begin{tabular}{lrrrrrr}
\hline \hline & Apr & \multicolumn{1}{c}{ May } & Jul & Sep & Oct & Average \\
\hline DO & 4.36 & 4.65 & 6.04 & 4.16 & 5.53 & 4.948 \\
\cline { 2 - 7 } & 55.48 & 58.31 & 74.24 & 53.36 & 72.61 & 62.86 \\
\hline Fecal Coli. & 1,500 & 1,200 & 9,300 & 20,000 & 46,000 & 15,600 \\
\hline pH & 6.19 & 7.89 & 8.66 & 8.32 & 7.36 & 7.684 \\
\hline BOD & 3 & 4 & 6.6 & 6.6 & 6.8 & 5.4 \\
\hline Temperatur & 27.2 & 26.3 & 25.1 & 27.7 & 29.2 & 27.1 \\
\hline PO4 & 0.11 & 0.69 & 0.77 & 0.01 & 0.09 & 0.334 \\
\hline NO3 & 1.17 & 2.78 & 10.56 & 3.42 & 3.15 & 4.216 \\
\hline Turbidity & - & - & - & - & - & - \\
\hline TSS & 15 & 48 & 76 & 58 & 17 & 43 \\
\hline \hline
\end{tabular}

TABLE IX: WQI PARAMETERS AT STA. PANUS BRIDGE 2013 [15].

\begin{tabular}{lrrrrrr}
\hline \hline & Apr & \multicolumn{1}{c}{ May } & \multicolumn{1}{c}{ Jul } & Sep & Oct & Average \\
\hline DO & 3.85 & 7.2 & 6.3 & 2.9 & 5.56 & 5.162 \\
\cline { 2 - 7 } & 47.9 & 92.07 & 78.52 & 37.14 & 72.55 & 65.61 \\
\hline Fecal Coli. & 2,100 & 36 & 1,500 & 46,000 & 2,100 & 10,347 \\
\hline pH & 6.54 & 7.88 & 9.18 & 7.64 & 7.32 & 7.712 \\
\hline BOD & 3.2 & 10 & 15 & 15 & 5.5 & 9.74 \\
\hline Temperatur & 26.2 & 27.9 & 26.3 & 28 & 29.2 & 27.52 \\
\hline PO4 & 0.12 & 0.68 & 0.02 & 0.01 & 0.08 & 0.182 \\
\hline NO3 & 2.3 & 2.47 & 9.67 & 4.32 & 3.51 & 4.454 \\
\hline Turbidity & - & - & - & - & - & - \\
\hline TSS & 29 & 64 & 97 & 22 & 18 & 46 \\
\hline \hline
\end{tabular}

IV. RESUlTS AND DISCUSSION

Based on information in Table III, each subwatershed is analyzed and classified into one of four categories. The results are plotted on Fig. 4.

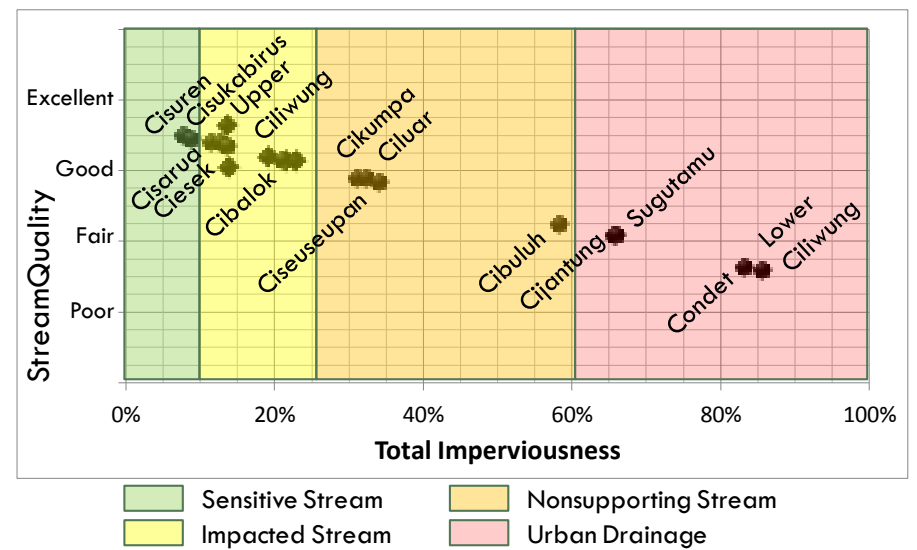

Fig. 4. Stream Quality Classification of Ciliwung According to ICM.

The results of ICM prediction are as follow: two sensitive streams (Cisuren and Cisukabirus), four impacted streams (Cisarua, Upper Ciliwung, Ciesek and Cibalok), four nonsupporting streams (Cikumpa, Ciluar, Ciseuseupan and Cibuluh), and four urban drainage (Cijantung, Sugutamu, Condet and Lower Ciliwung).

Since there is no existing water quality data which represents the quality of each subwatersheds, the WQI of 14 subwatersheds of Ciliwung were represented by the WQI at five stations: Atta'awun, Katulampa Weir, Kedung Halang, Pondok Rajeg and Panus Bridge. The WQIs are calculated based on the water quality data downloaded from the site of BPLHD Provinsi Jawa Barat (Table V-IX), and the results are presented in Table X.

TABLE X: WQI AT SAMPLING STATION OF CILIWUNG.

\begin{tabular}{|c|c|c|c|c|c|c|c|}
\hline \multirow[b]{2}{*}{ Station } & \multirow{2}{*}{$\begin{array}{l}\text { Imperviousness } \\
\text { up to Station }\end{array}$} & \multicolumn{6}{|c|}{ WQI 2013* } \\
\hline & & IV & $\mathrm{V}$ & $\begin{array}{c}\text { VI } \\
\text { I }\end{array}$ & IX & $\mathrm{X}$ & $\mathrm{Av}$ \\
\hline Atta'awun & $13.63 \%$ & 78 & 74 & 70 & 70 & 76 & 73 \\
\hline Katulampa Weir & $13.79 \%$ & 52 & 66 & 62 & 60 & 71 & 61 \\
\hline Kedung Halang & $19.08 \%$ & 71 & 61 & 67 & 59 & 64 & 64 \\
\hline Pondok Rajeg & $21.48 \%$ & 65 & 63 & 56 & 61 & 68 & 63 \\
\hline Panus Bridge & $22.80 \%$ & 64 & 74 & 59 & 54 & 71 & 63 \\
\hline
\end{tabular}

The correlation between imperviousness of a certain station, and the annual average WQI is represented by linear trendline $\mathrm{WQI}^{* *}=-48.799 \mathrm{x}$ Imperviousness $(\%)+73.66 ;\left(\mathrm{R}^{2}=\right.$ 0.1957). Table XI shows the estimated WQI at the outlet of each subwatershed. The results are plotted on Fig. 5. 
TABLE XI: SUBWATERSHED WQI OF CILIWUNG.

\begin{tabular}{lcc}
\hline \hline Subwatershed & $\begin{array}{c}\text { Subwatershed } \\
\text { Imperviousness }\end{array}$ & WQI** \\
\hline Upper Ciliwung & $13.6 \%$ & 67 \\
\hline Cisarua & $11.4 \%$ & 68 \\
\hline Cisuren & $7.7 \%$ & 70 \\
\hline Cisukabirus & $8.7 \%$ & 69 \\
\hline Ciesek & $12.5 \%$ & 68 \\
\hline Ciseuseupan & $47.5 \%$ & 58 \\
\hline Cibalok & $21.1 \%$ & 63 \\
\hline Cibuluh & $58.2 \%$ & 45 \\
\hline Ciluar & $34.1 \%$ & 52 \\
\hline Cikumpa & $31.1 \%$ & 58 \\
\hline Sugutamu & $65.9 \%$ & 42 \\
\hline Cijantung & $65.7 \%$ & 42 \\
\hline Condet & $83.2 \%$ & 33 \\
\hline Lower Ciliwung & $85.6 \%$ & 32 \\
\hline \hline **estimated based on linear trend: \\
WQI** = -48.799 x Imperviousness $(\%)+73.66$
\end{tabular}

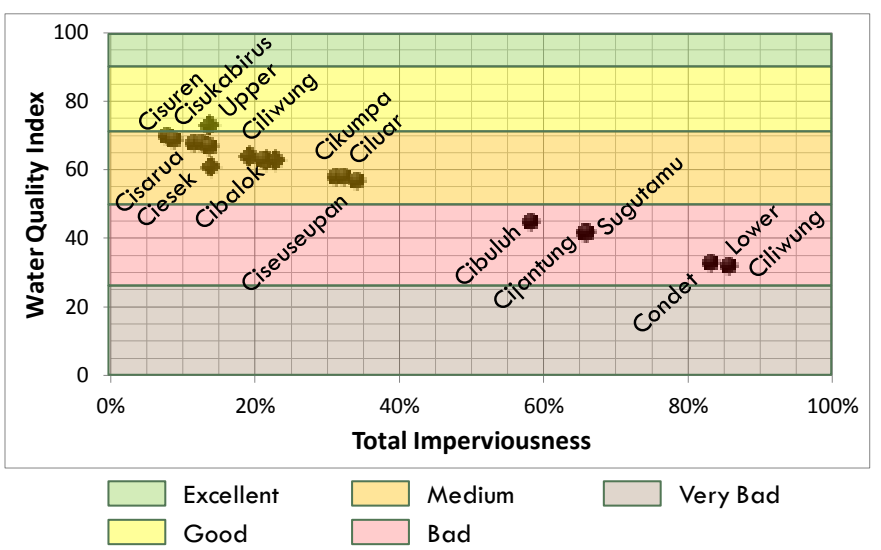

Fig. 5. Water Quality Rating of Ciliwung Based on WQI.

Fig. 5 shows the water quality rating (WQR) based on WQI classification: four subwaterheds which are categorized as urban drainage were rated as "bad" (Cijantung, Sugutamu, Condet and Lower Ciliwung), while the rest (10 subwatersheds) were rated as "medium".

The results of those two approaches consistently show that the sites nearest the headwaters (Sta. Atta'awun) have the highest water quality rating, with significant decreases in water quality occurring downstream, particulary in urban-impacted areas such as Cijantung, Sugutamu, Condet and Lower Ciliwung subwatersheds with the imperviousness greater than $60 \%$.

\section{CONCLUSION}

Prediction of stream quality with subwatershed scale (5 - 50 $\mathrm{km}^{2}$ ) using ICM and NSFWQI approaches proved consistently the premises that the sites near the headwaters, which usually have lower imperviousness, show the higher water quality rating and better stream quality. On the other hand, subwatersheds with higher imperviousness show the lower rating and worse stream quality.

Further research is needed in order to be able to quantify the relation between imperviousness and stream quality, since the conclusion was derived based on very limited secondary data. According to [7] the conclusion should be derived based on population of at least 20 subwatersheds and should be compare to the reference streams. Both selected and reference subwatersheds should fulfill the designated criteria, as stated in the proposed Protocol for Defining Functional Relationships Between Watershed Imperviousness and Stream Quality.

\section{ACKNOWLEDGMENT}

The author would like to thank to the Head of Board of Planning, Development and Control Universitas Indonesia (BP3UI), for supporting in part of the work, and to the West Java Province Environmental Management Agency (BPLHD Provinsi Jawa Barat), for the uploaded water quality data of Ciliwung. Special thanks are extended to Ardi and Evi, who have work out the digital map of Ciliwung provided by the Geomatics Information Agency (Badan Informasi Geomatika), as well as to Wira, who graciously provided me with land use analysis of Ciliwung from his Master days at Universitas Indonesia.

\section{REFERENCES}

[1] CWP, "Watershed Protection Research Monograph No. 1: IMPACTS of Impervious Cover on Aquatic Systems", Center for Watershed Protection, Ellicott City, MD, March 2003. Available: http://clear.uconn.edu/projects/tmdl/library/papers/Schueler_2003.pdf.

[2] J. Zielinski, "Watershed Vulnerability Analysis", Center for Watershed Protection, Ellicott City, MD, January 2002. Available: http://www.cwp.org/Vulnerability_Analysis.pdf.

[3] T.R. Schueler, L. Fraley-McNeal and K. Cappiella, "Is Impervious Cover Still Important? Review of Recent Research", Journal of Hydrologic Engineering, Vol. 14, No. 4, pp. 309-315, April 1, 2009. Available: http://ascelibrary.org/doi/full/10.1061/(ASCE)1084-0699(2009)14:4(309 ). http://dx.doi.org/10.1061/(ASCE)1084-0699(2009)14:4(309)

[4] BASIN, "The National Sanitation Foundation Water Quality Index", Boulder Area Sustainability Information Network, December 2005. Available: http://bcn.boulder.co.us/basin/watershed/wqi_nsf.html.

[5] Water Research Center, "Monitoring the Quality of Surface Waters, Calculating NSF Water Quality Index (WQI)", 2014. Available: http://www.water-research.net/index.php/water-treatment/water-monitor ing/monitoring-the-quality-of-surfacewaters.

[6] M. Wills and K.N. Irvine. "Application of the National Sanitation Foundation Water Quality Index in the Cazenovia Creek, NY", pilot watershed management project. Middle States Geographer, pp. 95-104, 1996.

http://msaag.org/wp-content/uploads/2013/04/12_Wills_Irvine.pdf.

[7] T. R. Schueler and H. K. Holland (editors), Article 1: "The Importance of Imperviousness", Feature article from Watershed Protection Techniques. 1(3): 100-111. The Practice of Watershed Protection, the Center for Watershed Protection, Ellicott City, MD, 2000. Available: http://scc.wa.gov/wp-content/uploads/2015/06/The-Importance-of-Imper viousness_Schueler_2000.pdf.

[8] BIG, "Data Penggunaan Lahan Se Jawa", Badan Informasi Geospasial, Cibinong Bogor, 2009.

[9] C. Bellucci, "Stormwater and aquatic life: Making the connection between impervious cover and aquatic life impairments for TMDL development in Connecticut streams", Proceedings of the Water Environment Federation, 2007 (5), 1003-1018. Available: http://clear.uconn.edu/projects/tmdl/library/papers/Bellucci_2007.pdf.

[10] C.L. Jr., Arnold, and C. J. Gibbons, "Impervious surface coverage: Emergence of a key environmental factor". Journal of the American Planning Association 62, 2: 243-58. 1996. Available: http://www.esf.edu/cue/documents/Arnold-Gibbons_ImperviousSurface Coverage_1996.pdf.

http://dx.doi.org/10.1080/01944369608975688 
[11] BPLHD Provinsi Jawa Barat, "Hasil Analisa Kualitas Air Ciliwung di Atta'awun Periode 2013”. Available: http://www.bplhdjabar.go.id/index.php/layanan/dokumen/kualitas-air/la mpiran-storet-sungai-ciliwung-2013/66-attaawun/file.

[12] BPLHD Provinsi Jawa Barat, "Hasil Analisa Kualitas Air Ciliwung di Bendung Katulampa Periode 2013". Available: http://www.bplhdjabar.go.id/index.php/layanan/dokumen/kualitas-air/la mpiran-storet-sungai-ciliwung-2013/68-katulampa/file.

[13] BPLHD Provinsi Jawa Barat, "Hasil Analisa Kualitas Air Ciliwung di Kedung Halang Periode 2013". Available: http://www.bplhdjabar.go.id/index.php/layanan/dokumen/kualitas-air/la mpiran-storet-sungai-ciliwung-2013/ 69-kedung-halang/file.

[14] BPLHD Provinsi Jawa Barat, "Hasil Analisa Kualitas Air Ciliwung di Pondok Rajeg Periode 2013". Available: http://www.bplhdjabar.go.id/index.php/layanan/dokumen/kualitas-air/la mpiran-storet-sungai-ciliwung-2013/70-pondok-rajeg/file.

[15] BPLHD Provinsi Jawa Barat, "Hasil Analisa Kualitas Air Ciliwung di Jembatan Panus Periode 2013". Available: http://www.bplhdjabar.go.id/index.php/layanan/dokumen/kualitas-air/la mpiran-storet-sungai-ciliwung-2013/67-jembatan-panus/file.

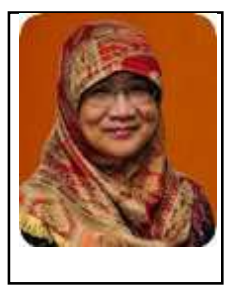

Dwita Sutjiningsih. Born in Purworejo, Indonesia on 29 October 1952. She finished her degree in Civil Engineering in 1977 at Civil Engineering Department, Faculty of Engineering Universitas Indonesia. In 1980/1981 she pursued the Diploma in Hydraulic Engineering with specialization in River Engineering, at the International Institute of Hydraulics Engineering, Delft, the Netherlands. Her doctoral degree in Civil Engineering with specialization in Hydrology was earned in 1994, at the University of

Hannover, Germany.

From 1978 up to now she is lecturing at the Department of Civil Engineering, Faculty of Engineering, Universitas Indonesia. In 2005-2014 she was appointed as the director of Directorate of Academic Development Universitas Indonesia. Her previous and current research interests cover stormwater management, erosion \& sedimentation management, and imperviousness \& stream quality relation.

Dr.-Ing. Sutjiningsih is member of committee responsible for articles review in Bi-annual International Conference Quality in Research, Faculty of Engineering Universitas Indonesia; Bi-annual International Conference of HATHI (Indonesian Association of Hydraulic Engineers); International Journal of Technology, Faculty of Engineering Universitas Indonesia. 